\title{
Chapter 8 \\ The Development and Theoretical \\ Controversy of SEP Licensing Practices \\ in China
}

\author{
Yang Cao
}

\section{Introduction}

Standards are part of our everyday lives, which enable products to communicate with each other and frequently give rise to substantial consumer benefits. Nowadays tens of thousands of standards are established by Standard Setting Organizations (SSO). About $80 \%$ of global merchandise trade is affected by standards and by regulations that embody standards. ${ }^{1}$ In terms of the United States (US)-European economic relationship, standards influence an estimated $\$ 200$ billion in transatlantic trade. ${ }^{2}$ Standards frequently make reference to technologies that are protected by patents. A patent that protects technology essential to a standard is called a standard essential patent (SEP). Nowadays, it is impossible to manufacture standard-compliant products without using technologies covered by one or more SEPs. Licensing from the patent owner of an SEP is a must for those standard-compliant products' manufacturers. The process of licensing of those SEPs has always been a big issue from practical and theoretical perspective. This chapter will elaborate on why licensing of an SEP is particularly challenging, the judicial and practical controversies surrounding SEP licensing, and the possible solution for future SEP licensing in China.

\footnotetext{
${ }^{1}$ Raymond G. Kammer, 'The Role of Standards in Today's Society and In The Future' (NIST, 2000) <https://www.nist.gov/speech-testimony/role-standards-todays-society-and-future> accessed 14 December 2017.

${ }^{2}$ ibid.
}

Y. Cao $(\bowtie)$

Shanghai University of Political Science and Law, Shanghai, China

e-mail: philcao@hotmail.com

(C) The Author(s) 2018

A. Bharadwaj et al. (eds.), Multi-dimensional Approaches Towards New Technology,

https://doi.org/10.1007/978-981-13-1232-8_8 


\section{Problem with SEP Licensing}

All implementers of SEP are required to obtain a license from the patent holders. When a patent is a part of standard, the patent owner has to explicitly permit the use of an SEP on a fair, reasonable, and non-discriminatory (FRAND) basis. This is called a FRAND commitment. Those SEP patent holders are then required to agree that they will make available the SEP to the public on FRAND terms. The effect of agreeing to FRAND is still unknown. From the Chinese Civil law perspective, some courts think that this kind of commitment confer a unilateral obligation on SEP holders. ${ }^{3}$ But the truth is FRAND commitment not only confers duty on SEP holders but also constrains the behavior of implementers of SEP. So, the FRAND commitment cannot be only regarded as a unilateral obligation. From a perspective of Chinese Contract Law, some scholars think FRAND commitment as a contract for third party's interest. Under the FRAND commitment, the SEP holder and a standard organization sign a contract and the contract stipulates that the SEP holder has the obligation to license his patents on FRAND basis. ${ }^{4}$ Though FRAND can be explained fairly clearly, putting them into practice gets complicated because of so-called lock-in and reverse lock-in effects.

FRAND commitments are designed to prevent the exploitation of unearned market power that patentees may gain from the incorporation of their patents into industry standards. Adoption of a standard thus greatly strengthens the bargaining position of an SEP holder relative to potential licensees and there is a possibility to obtain reasonable royalties from a large body of standard implementers. SEP holders also benefit when their technologies are adopted in a standard because it is generally easier to make compliant products utilizing one's own technology as opposed to those developed by some other party. A SEP holder's bargaining power surges because a prospective licensee has no alternative to licensing the patent and he is at the patentee's mercy. ${ }^{5}$ Without a FRAND commitment an SEP holder may engage in patent hold-up (the exploitation of the locked-in position of standard implementers) to obtain supra-competitive royalties that are significantly higher than what the SEP holder could have obtained before its patent was incorporated into the standard. ${ }^{6}$ "The purpose of the FRAND requirements ... is to confine the patentee's royalty demand to the value conferred by the patent itself as distinct from the additional value - the lock-in value - conferred by the patent's being designated as standard-essential." ${ }^{, 7}$ The nature of the FRAND commitment, however, leaves

\footnotetext{
${ }^{3}$ Iwncomm v Sony (2017) Beijing IP Court: No 1194 of Zhiminchuzhi.

${ }^{4}$ Liu Ying, 'Legal Meanings of FRAND commitment' (2017) 6 Electronic Intellectual Property. ${ }^{5}$ Apple Corp v Motorola Mobility (2012) United States District Court, ND Illinois, Eastern Division, 869 F Supp 2d 901.

${ }^{6}$ Joseph Farell and others, 'Standard Setting, Patents, And Hold-Up' (2007) 74 Antitrust Law Journal 603.

${ }^{7}$ Research In Motion Ltd v Motorola, Inc (2008) District Court, ND Texas 644 F Supp 2d 788.
} 
room for interpretation and creates the opportunity for SEP holders to renege on their commitments in order to capture the hold-up value of their patents. ${ }^{8}$

In SEP licensing environment, the bad behaviors of SEP holders are always carefully watched, but the implementer is not always innocent. They can reverse hold-up the SEP and get unfair advantage from SEP holders. Whereas alleged 'patent lock-in' supposedly results in excessive royalties, 'patent reverse lock-in' is undermining licensors attempts even to achieve FRAND terms or to complete any licensing. ${ }^{9}$ Normally a seller of a product can restrict practical access to his or her goods without payment just by refusing to sell them, but the holder of an intellectual property right like an SEP holder cannot restrict the implementers' access to the SEP technology which is freely available in the standards. SEP holder also cannot refuse to license. That is of course why the right to exclude given by the injunction plays such a significant part of intellectual property disputes, because it is the means by which the law seeks to put the intellectual property owner into the analogous position to an owner of tangible property such as a product or land. ${ }^{10}$ Thus, if a FRAND commitment prevents a SEP holder from ever seeking an injunction, SEP holders will have no means of pushing infringers to the negotiation table or to avoid licensee's hold-out. Put differently, standards are published publicly, so that the patented technologies comprising a standard are easy to infringe and the SEP holder has no strong tool to prevent the implementers to explore the SEP in bad faith.

Despite many years of speculation and recently adjusted claims, there is no empirical support for the theory of 'patent lock-in.' Various eminent experts refute allegations of systemic 'patent lock-in.' It is likely that 'patent lock-in' has not occurred in the context of standards and licensing of SEPs because of the FRAND licensing contracts and available recourse to the courts have ensured that licensees cannot be forced to pay 'excessive' licensing fees. ${ }^{11}$ 'Reverse Lock-in', which is also sometimes referred to as 'reverse hold-up', rather than 'patent lock-in' may instead be a prevalent problem. But the picture seems different in China. Recently, we see growing 'lock-in' and 'reverse lock-in' practices in China.

\footnotetext{
${ }^{8}$ Joe Kattan and Chris Wood, 'Standard Essential Patents and the Problem of Hold-Up' (2013) $<$ https://ssrn.com/abstract=2370113 or http://dx.doi.org/10.2139/ssrn.2370113> accessed 12 October 2017.

${ }^{9}$ Anne Layne-Farrar, 'The Economies of FRAND' in Daniel Sokol (ed), Antitrust Intellectual Property and High Tech Handbook (Cambridge University Press 2016) <https://ssrn.com/ abstract=2725959> accessed 23 October 2017.

${ }^{10}$ Unwired Planet v Huawei Technologies [2017] EWHC 711 (Pat).

${ }^{11}$ Keith Mallinson, 'Patent Hold-up and Hold-out' (IP Finance, 2016) <http://www.wiseharbor. com/pdfs/Mallinson $\% 20$ on $\% 20$ Holdup $\% 20$ and $\% 20$ Holdout $\% 20$ for $\% 20 I P \% 20$ Finance $\% 2016 \%$ 20Aug\%202016.pdf> accessed 13 September 2017.
} 


\section{SEP Licensing Practice and Regulations in China}

\subsection{Guidelines and Judicial Practice Related to SEP Licensing}

To avoid the 'lock-in' and 'reverse lock-in' in SEP licensing, the Chinese courts at different levels established number of rules and guidelines. It is worth noting that all those rules and guidelines are focused on the negotiation process, few of which mention how to calculate the royalties. Article 24 of the Interpretations (II) of the Supreme People's Court (SPC) on Several Issues concerning the Application of Law in the Trial of Patent Infringement Dispute Cases (effective as of April 1, 2016, SPC Interpretation (II)) provides that in an SEP licensing negotiation process, if the SEP holder deliberately avoids its FRAND obligations, causing failure to reach licensing agreement, and the accused infringer has no apparent fault for that failure, the court shall not uphold an injunction claim. That means during the SEP licensing process, both parties have to act in good faith and the injunctive relief is unavailable for an unwilling licensor against a willing licensee. However, the SPC Interpretation (II) does not address the availability of injunction under other circumstances, such as where both parties were negotiating in good faith, or both had fault, or the patent holder was acting in good faith and the implementer was acting in bad faith. Moreover, the SPC Interpretation (II) specifically refers to recommended national and industrial standards, without mentioning compulsory standards or international standards such as LTE and IEEE. According to the clarifications made by the SPC spokesman for publicizing the SPC Interpretation (II), there were controversial issues relating to SEP. Only provisions without dissenting opinions were included in the SPC Interpretation (II), and the remaining issues were left open to be resolved through judicial practices. ${ }^{12}$

On 20 April 2017, the Beijing High Court issued a Guideline for Patent Infringement (2017) (2017 Guideline). Articles 149-153 are SEP-related provisions under the sub-title of Non-infringement Defense. Articles 152-153 specifically set forth how injunctive relief is applicable where neither party is at fault, or both of them are at fault during SEP licensing negotiation. The 2017 Guideline provides that when neither party is at fault, to avoid an injunction, the implementer shall timely deposit an amount of its proposed royalty or provide guarantee to the court. This additional deposit requirement upon potential licensees was a result of intensive advocacy of some influential SEP owners. One of the major concerns of the SEP owners was that if injunctive relief is generally barred without any limitation as long as implementers had no fault in negotiations, it would ultimately harm further FRAND negotiations by increasing the bargaining power of the implementers. ${ }^{13}$ Guangdong High Court issued a Working Guideline for the Trial of Standard Essential Patent Dispute Cases

\footnotetext{
${ }^{12}$ Yin LI, Hui Zhang and James Yan, 'New Developments on SEP-Related Disputes in China' (Kluwer IP Law, 2017) <http://patentblog.kluweriplaw.com/2017/07/03/new-developments-seprelated-disputes-china/> accessed 24 October 2017.

${ }^{13}$ ibid.
} 
(for trial implementation) on 26 April 2018, which is primarily concerned with SEP disputes in the telecommunications sector. This Guideline established a fault-based test for injunctive relief and specified the particular aspects which should be taken into account when determining FRAND royalty rates.

From the above-mentioned interpretation and guidelines, we can see that Chinese courts are trying to solve the problem of lock-in and reverse lock-in through negotiation process. Generally courts require all parties in the negotiation process to act in good faith to avoid lock-in and reverse lock-in problem. Some kinds of behavior are sure to be deemed as acting in bad faith by the courts. The above interpretations and rules focus too much on the attitudes of the negotiating parties, but they do not solve substantial issues of SEP licensing i.e. the royalties. Except in very few circumstances, most SEP negotiations are centered around the amount of royalties. Because of the lock-in and reverse lock-in problems, it seems everyone is in an advantageous positions to harvest preferential results, and at the same time no one is in a good position to get a good result. So amount of royalties will always be a big issue.

\subsection{Injunction Issues for Failure of SEP Licensing}

There are lots of controversies surrounding an injunction granted for an SEP. In 2013, in a high-profile antitust case between Huawei v InterDigital Corporation (IDC) ${ }^{14}$ the SEP holder IDC was found to have abused its dominant position in the licensing market during its unsuccessful negotiation with the potential licensee, Huawei, and in its subsequent patent infringement actions against Huawei in overseas jurisdictions. The Chinese court held that IDC acted unlawfully when it sought injunctive relief against Huawei, in circumstances where Huawei had expressed its willingness to obtain a FRAND license and had acted in good faith during their license negotiation. On 22 March 2017, the Beijing IP Court handed down a landmark decision for Iwncomm $v$ Sony (Sony case), ${ }^{15}$ concerning an SEP in a designated national standard wireless communication. In this case, the Beijing IP Court set forth its views on the availability of injunction for SEP holders under three circumstances that were not provided by the SPC Interpretation (II). The court stated that an injunction could be granted to prevent a 'reverse lock-in' when the SEP holder had no fault and the implementer was acting in bad faith. The court also held that no injunction would be granted if both parties acted in good faith, and in the case where both parties are at fault leading to a failed license negotiation, it would assess and weigh the degree of each party's fault to determine whether to grant an injunction. The Beijing IP Court found Sony liable for not agreeing to a FRAND license and being an unwilling licensee. The court in this case granted the first FRAND-encumbered injunction in favor of an SEP holder in China. A most

\footnotetext{
${ }^{14}$ Huawei v InterDigital (2013) Guangdong High Court, No 305 of Mingsanzhongzi.

${ }^{15}$ Watchdata v Hengbao (2017) Beijing IP Court, No 1194 of Zhiminchuzh.
} 
recent case the court granted injunction for the SEP holder is Huawei $v$ Samsung (Samsung case). ${ }^{16}$ This case is about two 4G related SEP owned by Huawei. The court held that Huawei took a very active attitude toward the cross licensing of $4 \mathrm{G}$ related SEP owned respectively and Samsung intentionally delayed the negotiation, and Samsung has fault. So, Samsung should stop its infringing activity.

It seems that in Huawei $v$ IDC the Chinese courts constrained injunctive relief to narrow circumstances, and warned SEP holders to be very cautious before seeking injunction to avoid raising any competition law issues. Such pro-licensee approach was altered in the Sony and Samsung case. So from the current practices, no Chinese courts exclude the possibility of granting injunction for SEP licensing situations. It means that the possible users of SEP must first seek a license. An SEP holder's commitment to grant licenses on FRAND terms creates a legitimate expectation that the SEP holder will in fact grant such licenses, a refusal by the SEP holder to grant those licenses may constitute an abuse of dominance. ${ }^{17}$ So SEP holders will also have a duty to act in good faith and in a transparent manner. Judge Posner says that an injunction is inappropriate even if a defendant makes no counter-offer at all, given that a FRAND pledge is not conditioned on such behavior. ${ }^{18}$ Posner wrote:

By committing to license its patents on FRAND terms, Motorola committed to license the 898 [patent] to anyone willing to pay a FRAND royalty and thus implicitly acknowledged that a royalty is adequate compensation for a license to use that patent. How could it do otherwise? How could it be permitted to enjoin Apple from using an invention that it contends Apple must use if it wants to make a cell phone with UMTS telecommunications capability—-without which it would not be a cell phone. ${ }^{19}$

Obviously, almost all SEP disputes center on money issues. Generally an injunction is often conditioned on irreparable harm in China. Many Chinese courts have held that pure monetary damages may not amount to irreparable harm. So, it seems that the injunction granted in Sony case is a very unique situation. In the long run, injunction in an SEP situation would be rarely granted. In 2008, the Supreme Court held that currently the Chinese SSOs have not established rules for disclosing and using of patent information in standard, if a patent holder has participated in standard setting process or consented to incorporate his patent into national, industrial or local standards, it means a patent holder has implicitly agreed to license his patents and the third party's exploitation of patent is legal and no violation of patent rights. ${ }^{20}$ Now this public disclosure or usage rule is available, but it is not clear if the Supreme Court still hold the same position.

\footnotetext{
${ }^{16}$ Huawei v Samsung (2016) Shenzhen Intermediate Court, N0 816 of Guangdong 03 MINCHU.

${ }^{17}$ Case C-170/13 Huawei Technologies v ZTE Corp (2015) Judgement Of The Court (Fifth Chamber) ECLI:EU:C:2015:477.

${ }^{18}$ Apple v Motorola (2012) United States District Court For The Northern District Of Illinois Eastern Division, No 1:11-cv-08540.

${ }^{19}$ ibid.

${ }^{20}(2008)$ Supreme Court of China, No 4 of Mingsantazi.
} 


\subsection{Negotiation Process of SEP Licensing}

Because of lock-in and reverse lock-in problem in SEP licensing, Chinese courts always require the licensing parties to act in good faith. The Chinese courts have put forward some guidelines on how good faith can be inferred from the negotiation process. But what constitutes good faith is still unclear. Generally if the potential licensee explicitly expresses his willingness to have a bilateral negotiation, the SEP patent holder has the duty to provide patent information or provide specific conditions of license to the potential licensee in written form and in accordance with business and trading practices. The licensor shall give the licensee a time period to respond in accordance with the business practice and the trading custom. The SEP holder cannot obstruct or interrupt the process of negotiation without adequate reasons during the process of negotiation and cannot intentionally propose a clearly unreasonable condition, which results in a failed licensing agreement. According to the opinions in the Huawei case, a SEP holder must treat 'similarly situated' licensees in a similar manner. Overcharging one party for similar licensing condition is discriminatory. ${ }^{21}$ To avoid a reverse lock-in situation, the Chinese courts usually require the potential licensee to diligently respond within a reasonable time clearly stating the acceptability or unacceptability of the terms of the license. A licensee unable to accept specific conditions in a license should propose new conditions in the form of a counter offer. It means that a potential licensee cannot just ignore the licensing offer and he must clearly express whether he is willing to accept the terms of the license. If he refuses the offer, he must provide the licensor with a counter-offer. As a part of the counter-offer he cannot propose an apparently unreasonable condition. Obstructing, delaying or refusing to participate in a license negotiation without adequate reasons is deemed to be a serious issue in a SEP licensing matter.

Surely, the Chinese courts have very clear idea of the 'lock-in' and 'reverse lock-in' problems in SEP licensing process. Any party refusing to cooperate will be surely punished leading up to the possibility of granting an injunction. From the current practices, if the parties are willing to cooperate and actively participate in the negotiation process, they can be considered to act in good faith. In this regard, the licensing fee is always a key issue in the negotiation process and the court requires both the licensor and licensee to propose reasonable price. In Samsung case, the Shenzhen International Court held that Samsung's offer for 4G relate SEP licensing rate is unreasonable in case that Samsung offered a rate three times higher than Huawei offered when Huawei and Samsung are evenly matched on quality and quantity of 4G SEPs they held. In contrast, Huawei's offer to Samsung is reasonable considering the $3 \mathrm{G}$ and $4 \mathrm{G}$ related SEPs' strength of Huawei, the market price of Samsung $3 \mathrm{G}$ and $4 \mathrm{G}$ mobile phones and $3 \mathrm{G}$ and $4 \mathrm{G}$ related SEPs' aggregate licensing rate. The court held that the SEP licensing rate cannot be too high to surpass the normal profit level in that industry, and must make sure the licensees to

\footnotetext{
${ }^{21}$ Huawei (n 14).
} 
harvest reasonable operation profits. Currently, no guideline of what constitutes reasonableness is available in China. It is unclear as to what kind of royalty proposal will be regarded unreasonable. Further, it is not clear what standards are to be used to decide royalty rates. It seems, reasonableness means that the licensing parties acting as reasonable person in the same shoes believe that the price they proposed is proper. It is worth noting that reasonableness does not mean that the proposed price has to be same with the late court decided rate, which can be comparably similar. Justice Birss once held that a licensee cannot challenge a license allegedly granted on FRAND terms if it later discovers that a similarly-situated implementer received a lower royalty rate unless the difference would 'distort competition' between the two licensees. ${ }^{22}$ If both parties act in good faith and propose some reasonable price for the licensing, and still cannot agree on the royalty rate, the court then is required to decide what royalties are proper.

\subsection{Royalty Issues in SEP Licensing}

What amount of royalty meets FRAND is always a challenging question to answer. It seems that Chinese courts have taken different views on the issue of royalty. In 2008, the Supreme Court held that if a patent is incorporated into national, industrial or local standard, the patent holder can ask the implementers of the patent to pay a certain amount of fees, which should be apparently lower than the normal licensing fee. ${ }^{23}$ There is no additional help provided to understand the scope of 'normal licensing fee'. It seems, it is the licensing fee that the patent holder would get before a patent becomes essential. The question however remains as to why the royalty should be lower than the normal licensing fee? One possible explanation is that because the patent is incorporated into a standard, the patent holder is sure to have more potential users and this will certainly increase the amount of royalties. So, the patent holder can only ask for royalty less than normal licensing fee. The Chinese Supreme Court provides us with a very interesting way to calculate royalty.

In 2016, the Chinese Supreme Court held that the following factors should be considered before deciding the royalty rate: degree of innovation of the patent and its role in the standard, the technical field to which the standard belongs, the nature of the standard, the regional scope of exploitation and the relevant licensing conditions, etc. $^{24}$ In Huawei case in China, the court used InterDigital's license with Samsung, Apple, and others as comparable licenses to determine whether the royalty rate InterDigital offered to Huawei was discriminatory. This was also used as a possible reference point to calculate the appropriate FRAND royalty rate that should be charged to Huawei, which was determined to be no more than $0.019 \%$. The question remains when several licensing rates are available for reference, which

\footnotetext{
${ }^{22}$ Unwired Planet (n 10).

${ }^{23}$ Supreme Court of China (n 20).

${ }^{24}$ Supreme People's Court Interpretation (II), art 24.
} 
one shall the court adopt? In the above Huawei case, the Chinese courts adopted a so-called possible lowest rate policy. ${ }^{25}$ Clearly, Chinese courts rely heavily on comparable license agreements to determine FRAND. The comparable license fees are always important reference points in determining FRAND rate, but the court will adjust the fees in a reasonable manner. The Guangdong High Court in Huawei Case held that the following factors should be weighed in while considering the FRAND rate: first, the amount of royalties should take into account the profits derived from the implementation of the patent or similar patent and the proportion of the above profit to the whole profit or sales revenue of the licensee's related products. The technology, capital, licensee's operating labor and other factors together contribute to the final profit of a product. The patent royalty can only be part of the product's profit and not all, and the patentee does not provide all the technology the product needed. So, the patentee only has the right to receive a portion of the profit corresponding to his patent value in product. Second, the contribution made by the patentee is its innovative technology. The patentee can only obtain the additional benefits because of his patent technology not the standard. Third, the amount of royalty shall take into account the patentee's effective patent in the standard. It is unreasonable to require standard implementers to pay royalties for non-SEPs present in the standard. Fourth, royalties should not exceed a certain percentage of product profits, and should be reasonably distributed amongst SEP holders. In the US, the Georgia-Pacific case ${ }^{26}$ provides the most common framework for deciding damages in patent infringement cases. FTC recommended that courts use the concept of the hypothetical negotiation as the proper framework to determine reasonable royalties and suggested treating the other Georgia-Pacific factors as categories of information that might be relevant in predicting the outcome of the hypothetical negotiation. ${ }^{27}$ The judge in that case called for evaluating a 'hypothetical negotiation' between the two parties assuming they were both willing to conclude a license. He also listed a set of 14 other 'factors' that should be accounted for. US courts have relied on the Georgia-Pacific framework for over 40 years and it provided a framework for SEP license assessments. ${ }^{28}$ In Microsoft $v$

\footnotetext{
${ }^{25}$ According to the evidence of the case, IDC Company signed a license contract with Apple Company for a term of seven years in 2007 and adopted a one-time payment method. The license fee is calculated at a license rate of $0.0187 \%$. IDC Company proposed license rates to Huawei a hundred times higher than Apple (which is about 2\%). IDC gives Samsung a royalty rate of about $0.19 \%$.

${ }^{26}$ Georgia-Pacific Corp v United States Plywood Corp (1970) United States District Court, S D New York, 318 F Supp 1116.; modified sub nom. Georgia-pacific Corporation v U S Plywood (1971) US Court of Appeals for the Second Circuit, 446 F2d 295.

${ }^{27}$ Federal Trade Commission, 'The Evolving IP Marketplace: Aligning Patent Notice And Remedies With Competition' (FTC, 2011) <https://www.ftc.gov/sites/default/files/documents/ reports/evolving-ip-marketplace-aligning-patent-notice-and-remedies-competition-report-federaltrade/110307patentreport.pdf $>$ accessed 8 June 2017.

${ }^{28}$ Anne Layne-Farrar and Koren W. Wong-Ervin, 'Methodologies for Calculating FRAND Damages: An Economic and Comparative Analysis of the Case Law from China, the European Union, India, and the United States' (2018) 8 Jindal Global Law Review.
} 
Motorola, Judge Robart modified the traditional Georgia-Pacific factors to determine a FRAND royalty rate. ${ }^{29}$ Several federal district courts in US have weighed in on a framework for determining a reasonable royalty for FRAND-encumbered SEPs. These courts have employed various methodologies, including using a modified version of the Georgia-Pacific factors that accounts for the value of the SEPs that contribute to the standard, the importance of that standard to the infringing products, and the aggregate royalty demands for firms implementing a complex standard with many essential patented technologies, typically known as the 'royalty-stack. ${ }^{30}$ In Unwired Planet $v$ Huawei, Justice Colin Birss offers two possible methods of calculating the FRAND royalty: one based on an analysis of comparable license rates, and the other based on a top-down analysis of the total aggregate royalty that should be attributable to the standards and SEPs at issue. In addition to disregarding the US Georgia-Pacific framework, which clearly has no place in a UK decision, Justice Birss rejects another touchstone of US FRAND analysis. The notion that a FRAND royalty should reflect the ex-ante value of the patented technology without considering any value attributable to the adoption of the technology in a standard. ${ }^{31}$ Without the baggage of Georgia-Pacific to clutter the analytical exercise, Justice Birss focussed on the actual task at hand: computing the value of the patented technology as compared to the standard and product at issue.

In sum, the following methods are used in deciding royalty rate worldwide:

\section{Comparable Method}

This approach, seen in rulings from China, the UK, and the US thus far focuses on just two of the Georgia-Pacific factors: factors 1 and 2 on comparable licenses. This method attempts to assess the value of asserted SEPs in isolation using comparable license agreements and other methodologies but without significant reference to other patents covering the same standard. ${ }^{32}$

\section{Top-Down Methodology}

Under the top-down method, the FRAND royalty equals $\mathrm{T} \times \mathrm{S}$. $\mathrm{T}$ is the total aggregate SEP royalty burden of a particular standard on a product, and $\mathrm{S}$ is the share of that aggregate royalty that is allocable to the SEP holder. The top-down approach involves firstly to determine the aggregate royalty that should be paid for

\footnotetext{
${ }^{29}$ Microsoft v Motorola (2012) United States Court of Appeals for the Ninth Circuit, 696 F3d 872.

${ }^{30}$ Edith Ramirez, 'Standard Essential Patents and Licensing: An Antitrust Enforcement Perspective' (FTC, 2014) <https://www.ftc.gov/system/files/documents/public_statements/ 582451/140915 georgetownlaw.pdf> accessed 26 July 2017.

${ }^{31}$ Jorge Contreras, 'Unwired Planet $v$ Huawei: An English Perspective on FRAND Royalties' (Patently-O, 2017) <https://patentlyo.com/patent/2017/04/unwired-perspective-royalties.html> accessed 23 October 2017.

${ }^{32}$ 'Jorge Contreras: TCL V. Ericsson: The First Major US Top-Down FRAND Royalty Decision' (Patently-O, 2017) <https://patentlyo.com/patent/2017/12/contreras-ericsson-decision.html?utm _ source=feedburner\&utm_medium=email\&utm_campaign=Feed\%3A+PatentlyO+\%28Dennis +Crouch\%27s+Patently-O\%29> accessed 29 December 2017.
} 
all SEPs covering a particular standard, and then to allocate an appropriate portion of the total to the asserted SEPs. ${ }^{33}$

3. Hypothetical Negotiations

The purpose of conducting hypothetical negotiation is to ascertain the royalty upon which the parties would have agreed had they successfully negotiated an agreement just before infringement began. The court must try to recreate the ex-ante licensing negotiation scenario and describe the resulting agreement. ${ }^{34}$ When using this method, a few differences have to be noticed.

Whether a FRAND royalty should reflect the ex-ante value of the patented technology? Justice Birss rejected the notion that a FRAND royalty should reflect the ex-ante value of the patented technology, without considering any value attributable to the adoption of the technology in a standard. Judge Robart in the Motorola case held that the exercise must reconstruct the negotiation that would have taken place between the parties prior to the date on which the patented invention was adopted as a part of the industry standard.

The courts in US apply a modified version of the Georgia-Pacific factors to address the unique circumstances of SEP licensing to recreate a hypothetical negotiation between the parties as the best starting point for FRAND assessments. The Chinese courts on the other hand seems to be adopting a more narrow factor to determine royalty rate.

A FRAND license must be non-discriminatory. This means that the licensor must not discriminate against similarly-situated licensees. So comparable method is an important method in determining royalty rate. Comparable method however will only provide a base for calculating royalty rate. The prohibition on discrimination would mean very little if the largest, most profitable firms could always be a category unto themselves simply because they were the largest and most profitable firm. ${ }^{35}$ Generally, comparable method is always a good method for determining non-discrimination. The comparable method usually provides an appropriate base for valuing royalty rate, but what rate is fair and reasonable must be decided by other way. The Chinese courts clearly use the Top-Down Methodology and Hypothetical negotiations simultaneously. The Guangdong High Court clearly points out that the royalty rate should be decided on technology per se and should not harvest supra-competitive profits because of it being incorporated into a standard. It surely borrows some ideas from Hypothetical Negotiations method. To decide the specific amount of royalty rate, the court also uses the top-down methodology in considering the contribution that the SEP made to the profits and allocating an appropriate portion

\footnotetext{
33 ibid.

${ }^{34}$ In re Innovatio IP Ventures, LLC Patent Litigation (2013) United States District Court, N.D. Illinois, Eastern Division, MDL Docket No. 2303 Case No. 11 C 9308.

${ }^{35}$ TCL Communications v Ericsson (2017) United States District Court Central District Of California, Case No: SACV 14-341 JVS (DFMx) and CV 15-2370 JVS (DFMx).
} 
of the total to the asserted SEPs. ${ }^{36}$ The Chinese courts seem to take a more flexible method in justifying its royalty decision. But we did not see what specific method the court had adopted in calculating specific royalty rate.

Some scholars think that a court should not adjudicate the pure FRAND royalties dispute. ${ }^{37}$ The freedom of contract is essential to good and sound operation of market economy. If the parties cannot reach to an agreement on specific price of royalty, a court-determined FRAND rate is a breach of freedom of contract and sometimes it is rather difficult for the court to ascertain because of the complex royalty licensing calculation. But the courts are surely not agreeing with these holdings and believed that they have the legal obligations to adjudicate any dispute arising from SEP licensing issues.

\section{Solution to SEP Licensing Lock-in Problems}

It is difficult to ascertain the exact royalty rate in a given situation. Rather than the court the licensing parties would know the optimal rate. All those methods adopted by different courts are causing controversy and do have certain shortcomings. The use of comparable licenses has been criticized on the basis that most licenses are not really comparable to the desired FRAND license. ${ }^{38}$ This method does not reflect the diversity and evolving dynamics of SEP markets. So what is the possible solution to this impossible mission? Empirical study shows that in a SEP licensing situation the patent holders are always actively participating in the negotiation process and have strong desire to reach an agreement because most courts are somewhat hostile to SEP holders and never grant excessive damages even in cases of infringement. ${ }^{39}$ So from practical point of view, the 'reverse lock-in' problem should be the focus of regulations. In that situation the SEP users intentionally ignore their duty of negotiation and are unwilling to pay the royalty rate on FRAND basis. In fact, the SEP holders have very limited options to push the SEP users to the negotiation table and force them to pay the licensing fees. One of the powerful tools the SEP holders have is injunction. In China, most courts are unwilling to grant injunction for the unlicensed use of SEP. Until now only two cases (Iwncomm v Sony and Huawei $v$ Samsung) have granted injunction for the unlicensed uses. Hopefully, more injunctions will be granted in SEP licensing situation to push SEP users to the negotiation table. In Samsung case, the Shenzhen Intermediate Court held that the injunction relief in SEP case should differ from Non-SEP case. The court states that

\footnotetext{
${ }^{36}$ Huawei (n 14).

${ }^{37}$ Ma Haisheng, 'The Impossibility of Judicial Determination of Royalty Rate' Intellectual Property Magazine (2016) 12.

${ }^{38}$ Jonathan S. Masur, 'The Use And Misuse Of Patent Licenses' (2015) 110 Northwestern University Law Review 115.

${ }^{39}$ Alexander Galetovic, Stephen Haber and Ross Levine, 'An Empirical Examination Of Patent Hold-Up' (2015) 11 Journal of Competition Law \& Economic 549.
} 
because of the nature of these cases involve 4G SEPs, the parties may continue to negotiate after the decisions become effective. If the parties reach an agreement and request the court not to execute the court order, such request should be granted.

Generally, the licensing royalties should be negotiated on the basis that is mutually beneficial to the SEP holder and the licensee. If the patented technology allows the licensee to drastically reduce costs or increase sales over competing technologies, the licensee should be willing to pay more. ${ }^{40}$ Surely the SEP holders are also willing to license their patents and the potential licensors have to use the SEP, so both parties have strong desire to reach a mutually beneficial agreement. The licensing contract is sure to leave both the parties in a better position if agreed on voluntary base. So, the courts should constrain from determining the royalty rate. The current regulation should focus on how the participants act in the negotiation process. The Chinese Contract Law clearly specifies that all participants must act in good faith. The breach of good faith duty is liable for culpa in contrahendo. Besides, the existing rules in contract law are highly recommended for a relevant authority to establish national rules for SEP licensing negotiation. There are no national rules for negotiation process and some rules are scattered at different places. The national rule shall infuse more clarity and flexibility by highlighting the bilateral negotiation as the principal forum for determining FRAND.

The courts shall decide a specific royalty rate only if both participants failed to reach an agreement even after acting in good faith. Due to difficulty in rates determination, the author thinks it may be best for the court to emphasize on the FRAND range instead of rates. The courts can narrow rates to a certain range between willing-to-pay and willing to accept and push the participants to have further negotiation on that base. The courts may point out to some rules that the negotiators must follow such as: good faith, no discrimination against similarly situated licensees ${ }^{41}$ the way of determining the aggregate SEP royalty applicable to a standard, and the proportion of profits allocable to the asserted SEPs. In the process of narrowing the rates in the scope of bargaining range, the courts would have taken into account interests of both parties.

\section{Conclusion}

SEP royalty rate will always be a big topic in technology licensing field. 'Lock-in' and 'Reverse Lock-in' are obstacles both parties have to overcome. Both parties have strong desires to conclude an agreement concerning SEP licensing. What kind of measures should be taken to push the licensing parties to negotiation table and

\footnotetext{
${ }^{40}$ Ramirez (n 30).

${ }^{41}$ TCL Communication (n 35); The court held that low-end vendors would be compared with high-end vendors like as to FRAND rates, giving low-end vendors the benefit of favorable rate packages that high-end vendors have been able to negotiate with respect to far more expensive products.
} 
expedite the SEP negotiation process should be key concerns in SEP licensing situations. What the Chinese courts did currently is to confer a duty of good faith on both parties. But a good faith duty is still not enough to bring a good result. Deadlock sometimes seems inevitable even when both parties have no bad faith. So, the future job should be focused on solving that deadlock. The court always has no such capacity to decide the specific amount of royalty. When both parties exhaust efforts to arrive at a royalty rate on FRAND terms but are not successful, then it is better to allow independent experts or organizations to decide the royalty rate.

Open Access This chapter is licensed under the terms of the Creative Commons Attribution 4.0 International License (http://creativecommons.org/licenses/by/4.0/), which permits use, sharing, adaptation, distribution and reproduction in any medium or format, as long as you give appropriate credit to the original author(s) and the source, provide a link to the Creative Commons license and indicate if changes were made.

The images or other third party material in this chapter are included in the chapter's Creative Commons license, unless indicated otherwise in a credit line to the material. If material is not included in the chapter's Creative Commons license and your intended use is not permitted by statutory regulation or exceeds the permitted use, you will need to obtain permission directly from the copyright holder.

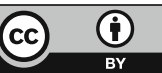

